\title{
Examining acculturation orientations and perceived cultural distance among immigrant adolescents in Portugal: links to performance in reading, mathematics, and science
}

\section{Michael Melkonian $^{1}$ • Shaljan Areepattamannil ${ }^{1}$ - Luisa Menano ${ }^{1}$. Patricia Fildago ${ }^{1}$}

Received: 25 September 2018 / Accepted: 14 May 2019 / Published online: 4 July 2019

(c) The Author(s) 2019, corrected publication 2020

\begin{abstract}
Drawing on data from the fifth cycle of the Program for International Student Assessment (PISA), the authors examined the relations of reported acculturation orientations-heritage as well as host culture-orientations-and perceived cultural distance between host and heritage culture with academic performance among 399 first- and second-generation immigrant adolescent students in Portugal. Results of hierarchical regression analyses, after accounting for student demographic characteristics, revealed a positive relationship between host culture-orientations and the first-generation immigrant adolescents' performance on the PISA reading, mathematics and science assessments, and also the second-generation immigrant adolescents' performance on reading assessment. Additionally, both the first- and secondgeneration immigrant adolescents' heritage culture-orientations were significantly negatively linked to performance on the PISA reading, mathematics, and science assessments. Furthermore, findings revealed that first-generation immigrant adolescents' perceived cultural distance was significantly negatively associated with their performance on the PISA reading and mathematics assessments. Implications for policy and practice are discussed.
\end{abstract}

Keywords Acculturation orientations - Perceived cultural distance $\cdot$ Academic performance $\cdot$ First-generation immigrant adolescents $\cdot$ Second-generation immigrant adolescents

Michael Melkonian

mmelkonian@ecae.ac.ae

1 Emirates College for Advanced Education, Abu Dhabi, United Arab Emirates 


\section{Introduction}

The movement of peoples across the globe, be it for the short or long term, has been a persistent and fundamental component of the human condition. The history of humankind is an ongoing record of this passage of migratory movement both voluntary and involuntary that results from an interplay of differing personal, social, political, and environmental factors. Regardless of the determinants of the migration, an improved quality of life is a common element within the reasons given by migrants for leaving their home country (Blomquist 2006). Such improvements are desired on a variety of socio-economic dimensions (Massey 1990; Massey et al. 1994), and are often cited as a major determinant of the migration, with better opportunities of success for the family of the migrant being high on the list of anticipated improvements.

As immigration shapes and dramatically changes the demographic landscape of immigrant-receiving societies across the globe (International Organization for Migration 2013), a pertinent understanding is that as people migrate, irrespective of the reasons underlying their move, their ideals, values, and beliefs travel with them (Phinney et al. 2001), and that this inevitable heritage cultural-orientation will to a greater or lesser extent overlap with the culture or cultures of the receiving nation. Additionally, and more so for long term immigrants than for short term migrants, there is the pressure and challenges of the accompanying acculturation process that is part of adaptation to life in the new environment. A corresponding pressure and challenge is felt by the host nation as a whole and is a primary policy concern for governments, as large-scale immigration increases within immigrant-receiving countries is helping immigrants, particularly immigrant children be they first-generation (i.e., born outside of the host nation and whose parents were also both born outside of the host nation) or second-generation (i.e., born in the host nation but whose parents were born in another country (see OECD 2013) to acculturate and adjust to their new lands (see Berry et al. 2006; Bourhis et al. 1997; Dimitrova et al. 2014; Suárez-Orozco et al. 2008). There is, therefore, a recurrent need for research that provides both migrants and immigrant receiving countries an improved understanding of the factors that facilitate successful acculturation and positive life chances.

\section{Theoretical background}

\subsection{Acculturation orientations}

Much research has sought to establish the potential influence of acculturation on immigrant populations and has unearthed the intricate relations of immigrant acculturative processes with immigrant health and well-being in general and mental health in particular (see Berry et al. 2006; Dimitrova et al. 2014; Trinh et al. 2009). Also of particular interest has been exploration of links between 
acculturative processes and learning outcomes among immigrant adolescents (e.g., Dustmann et al. 2011; Jia et al. 2014) and the relationships of acculturation orientations with educational achievement among immigrant children and youth (e.g., Kim et al. 2013).

However, the notion of acculturation, as a process of acquisition of cognitive and behavioural orientations that enable immigrants to adapt to a host culture both psychologically and socio-culturally (Schwartz et al. 2010), has undergone significant scrutiny and transformation (e.g., Arends-Tóth and Van de Vijver 2006; Berry 1997, 2003, 2017; Bourhis et al. 1997). Inquiry has focussed on a variety of the facets of acculturation, including the manner in which acculturation processes operate, e.g., in a unidimensional or bidimensional manner (Ryder et al. 2000) and the social and psychological contexts in which acculturation occurs (e.g., Arends-Tóth and Van de Vijver 2006; Berry 2017).

The previously traditional unidimensional view of acculturation as part of an assimilationist model as presented by Gordon (1964) suggests that cultural adaptation lies on a single dimension that has identification with the heritage culture at one end and identification with the dominant host culture at the other. Therefore, the acquisition of adaptive patterns of thought and behaviour of the host culture by immigrants is accompanied by a necessary loss of identification and movement away from ones heritage culture (Gordon 1964). Nevertheless, a growing body of research has suggested that acculturation cannot be adequately understood as unidimensional (Berry 1997; Bourhis et al. 1997; Ryder et al. 2000; Schwartz et al. 2010).

In contrast to the unidimensional model of acculturation, the bidimensional approach (Berry 1997, 2003) considers the acculturative process not to operate along a single dimension, but rather two independent albeit related dimensions. The first dimension concerns the relative maintenance of the heritage culture, the extent to which migrants seem to preserve or neglect their heritage culture and identity, whilst the second dimension refers to the interaction with the host culture, i.e., the amount of contact and involvement engaged in by migrants with host groupings and the host culture. According to Berry (1997), the relative intersection of the two dimensions, of heritage cultural maintenance and host culture interaction, yields four generalized cultural orientation strategies that individuals may adopt: assimilation, separation, integration, and marginalization. Assimilation occurs when the adoption of attributes that enable interaction with non-heritage culture is prioritized over maintenance of heritage culture attributes. Separation follows maintenance of the original culture and avoidance of non-heritage culture interaction. Integration describes the desire to maintain the heritage culture while utilizing other culture features that promote success and positive interactions within the larger society. The fourth orientation is marginalization, where individuals (voluntarily or involuntarily) neither maintain the cultural characteristics of the heritage culture, nor assume the characteristics of the larger host culture or cultures. Consequently, the bidimensional model provides a framework of understanding of the diversity of cultural orientation strategies migrants may exhibit and of integration as a pluralistic stance that allows for both the maintenance of identification to the heritage culture and adaptive participation within a host culture. In this sense, despite the lack of clear consensus regarding the concept of integration (Boski 2008; Esser 2006; Snauwaert et al. 2003; Ward 2013) 
as a bicultural attitude, it is considered desirable in terms of both psychological and sociocultural adjustment (e.g., Bankston and Zhou 1997; Berry 1997; Berry et al. 2006; Mok et al. 2007; Nguyen and Benet-Martínez 2013; Ward et al. 2011).

The adoption and usage of the bi-dimensional cultural orientation strategies by migrants is, however, neither straightforward nor consistent, whereby individuals assume just one cultural orientation by which to live. A growing corpus of research has revealed the complex nature of the acculturation process and the conditions under which migrants' adopt, utilize and/or blend differing cultural orientation strategies in relation to their context and domain specific considerations or requirements (e.g., Arends-Tóth and Van de Vijver 2006; Berry 2017; Bourhis et al. 1997; MottiStefanidi 2015; van Oudenhoven and Ward 2013; Ward 2013).

With regard to the nature and characteristics of the interacting groups and the circumstances of their interaction, a number of contextual factors have been considered that can predispose the adoption of a particular orientation strategy: the presence of more than one dominant ethnic/cultural group (van Oudenhoven and Ward 2013); the nature of the migration, e.g., whether the migration is temporary-permanent, voluntary-involuntary, sedentary-migrant (Berry 1990); the occurrent characteristics of both the society of origin (e.g., homogeneity and ethnic vitality) and the receiving society (e.g., cultural openness and level of discrimination) (Van De Vijver and Phalet 2004; Bourhis et al. 1997; Motti-Stefanidi 2015). Moreover, it has also been shown how adoption of different cultural orientation strategies are not only influenced by situational factors or as the result of dispositional factors instrumental in maintaining the smooth flow of migrants' daily lives in different domains of engagement, e.g., social, work and education, through private or public choices of food, clothes, language, work (Arends-Tóth and Van de Vijver 2003, 2006; Güngör 2007); but alternation and blending of orientations also is considered useful to establishing a balanced and integrated identity across areas such as religion, family and friends (Ward 2013). Therefore, the relative presence and interplay of these features and the orientations adopted can in turn influence the resultant intergroup relations, e.g., in terms of considered social inequality and social distance, and therefore potentially mediate the subsequent orientation strategy choices that are made.

With respect to academic achievement, acculturation research suggests the success of immigrant students in areas such as education to be an outcome of the level and nature of identification and contact with the host and heritage culture (Berry 1997; Bourhis et al. 1997, 2010), the reception and support provided by the immigrant receiving society (e.g., Motti-Stefanidi 2015), and the specific cultural values, orientations and expectations toward education that are held by the heritage culture to which the immigrant student and family belongs (e.g., Feliciano and Lanuza 2017).

Specifically of relevance to the current study, research suggests that the relationship between acculturation orientations and academic performance is dynamic and not the same across all cultures (e.g., Kao and Tienda 1995) or even across successive generations within a given culture (Duong et al. 2016) due to the dynamic nature of the acculturative process.

Additionally, the variation regarding influence of parental and cultural values on formation of cultural orientations and the educational outcomes of immigrant youth 
is widely reported (e.g., Berry 2005; Kao and Tienda 1995; Kerr 2007; Niemeyer et al. 2009; Plunkett and Bámaca-Gómez 2003; Shin 2004; Vollebergh et al. 2001) and implicated within the "immigrant paradox" (e.g., Feliciano and Lanuza 2017; Fuligni 1997; Greenman 2013; Portes and Rumbaut 2001; Rosenbaum and Rochford 2008). Moreover, the influence of parental values is demonstrated in differing findings for both first- and second-generation immigrant students regarding the link between higher levels of educational achievement and identification with the heritage culture (e.g., Bankston and Zhou 1997; Fuligni et al. 2005; Gibson 1988) or host culture (e.g., López et al. 2002; Trickett and Birman 2005; Wood and Clay 1996).

Consequently, research that assists improved understanding of the varying patterns of bidimensional acculturation, the investigation of differing aspects of acculturative dynamics within individual immigrant receiving nations and across immigrant generations becomes increasingly relevant. To this end, one aspect of the dynamic focused upon within the current study is the relationship between first- and second-generation immigrant cultural orientations and academic performance.

\subsection{Perceived cultural distance}

For the purpose of the current study it is useful to distinguish between two related but distinct concepts, cultural distance and perceived cultural distance. Cultural distance is a measure of how much (or little) overlap exists between two cultures, whereas perceived cultural distance more specifically refers to an individual's subjective report of considered similarities and differences between social and physical aspects of home and host culture environments. Research has found the degree of cultural distance to be associated with the level of stress experienced and ease with which migrants adapt to a new cultural environment (e.g., Searle and Ward 1990; Ward and Searle 1991). Although investigation and measurement of cultural distance has been attempted objectively through the use of proxy measures such as a nation's Gross Domestic Product (GDP), adaptation of measures of cultural values (e.g., Schwartz 1992), and cultural dimensions (Hofstede 1980, 2001), it has been shown that subjective measures of cultural differences, i.e., perceived cultural differences are better predictors of acculturation related outcomes (Cheng and Leung 2013; Suanet and van de Vijver 2009). Hence, in keeping with other studies (e.g., Babiker et al. 1980; Searle and Ward 1990), the cultural distance data in the current study was obtained through a more subjective means of data collection, the selfreport of perceived cultural distance.

This concept of perceived cultural distance, based on the work by Babiker et al. (1980), is an important aspect of the acculturative process in that it can gauge a migrants subjective evaluations of differences between the heritage and host cultures and consequently be influential upon the level of stress migrants may experience upon entry to a new country (Babiker et al. 1980; Mumford 1998; Searle and Ward 1990; Suanet and van de Vijver 2009).

Furthermore, these subjective evaluations of experiences as judgements of the similarities and differences between the heritage and host culture are considered to influence immigrants' interactions and assessments of opportunity (Galchenko 
and van de Vijver 2007a, b; Suanet and van de Vijver 2009) and success within the receiving nation (Suanet and van de Vijver 2009; Ward 2001; Ward and Kennedy 1993). Additionally, as the nature of perceived cultural distance changes over immigrant generations as a function of the acculturation process, so can the level of ethnocultural identity conflict experienced (Ward 2007), which, in turn, may influence the level of stress experienced (Kibria 2000), the quality of intercultural interaction, and hence student achievement.

Within the educational environment, the stress induced by a combination of inexperience with the host culture and cultural distance can further reduce the opportunities for successful sociocultural adaptation in general (Galchenko and Van De Vijver 2007a, b) and the likelihood of bicultural competence (e.g., Benet-Martínez and Haritatos 2005; Berry 2005; Bourhis et al. 2010; LaFromboise et al. 1993). The lower the bicultural competence, i.e., the possession of attributes an individual needs to successfully manage life in two cultures (LaFromboise et al. 1993), the poorer the cultural fit of the students to the culture of the host nation and its educational system the greater the likelihood of poor adjustment within the school system (Ward 2001; Ogbu 1992; Schachner et al. 2014a) which, in turn, may lead to student achievement being negatively influenced as a consequence of increasing perceived cultural distance (Babiker et al. 1980; Rienties and Tempelaar 2013).

The majority of studies exploring the relationships between perceived cultural distance and academic performance have been conducted on temporary stay migrants (e.g., international students). To the knowledge of the authors, no study has explicitly examined the links between perceived cultural distance and academic achievement amongst first- and second-generation immigrant adolescent students. Consequently, it is of relevance to investigate the presence or absence of a link between the reported perceptions of cultural distance by first- and second-generation immigrant student adolescents and levels of academic achievement, and, therefore, to aid clarification of factors implicated in the adaptation to and success within the host nation.

\subsection{Host country language proficiency and academic performance}

The relationship between language proficiency and academic performance within immigrant youth populations is well reported (e.g., Han 2012; Kim and SuárezOrozco 2015; Suárez-Orozco et al. 2010). Nevertheless, despite research demonstrating a generally positive influence of host language proficiency upon academic achievement (e.g., Areepattamannil and Kaur 2012; Portes and Rumbaut 2001; Suárez-Orozco et al. 2008), it is not always the case that language proficiency invariably improves academic achievement. Studies investigating a variety of acculturation elements at play within immigrant groupings in the United States (e.g., Colon and Sanchez 2010; Trickett and Birman 2005) showed that host language proficiency is not necessarily a principle driver of academic achievement. Host language proficiency was not found to be significantly associated with academic achievement, whereas other elements of the acculturation process such as relating 
to the mainstream grouping (Colon and Sanchez 2010) and identification with the host culture (Trickett and Birman 2005) are significantly associated with academic achievement.

Traditional acculturation research (e.g. Berry 2006) has demonstrated the importance of host culture language proficiency in various aspects of the acculturation process, including indicating the level of acculturation (Clément 1986), reducing acculturative stress (Santiago et al. 2014), facilitating cultural adjustment (Yeh and Inose 2002; Yeh 2003). Conversely, the lack of language proficiency is considered an important component in perceived cultural distance (Babiker et al. 1980) between the original (i.e., heritage) culture and host culture, and has been implicated as a factor in acculturation orientations and outcomes (Berry 1992; Searle and Ward 1990).

\subsection{Language proficiency and academic performance in the Portuguese context}

The indistinct relationship between language proficiency and academic achievement is also in evidence within the country of investigation. Like other European countries with a colonial past, Portugal has seen an ebb and flow of migration, often of peoples from countries with which it has historical links including the former colonies of Angola, Brazil, and Cape Verde. Recent figures place the percentage of immigrants from former colonies at $41.9 \%$ (Portuguese National Statistics Institute 2013). Research in Portugal has suggested the relationship between language proficiency and academic achievement is not straightforward (e.g., Baganha and Marques 2001; Seabra 2012). Within Portugal, the acceleration of the immigration from the 1990s was largely driven by labour demand, particularly in the construction and specific services sectors with large numbers of immigrants arriving from former Portuguese colonies of Angola, Cabo Verde, Mozambique, Brazil, Guine Bissao, and São Tomé and Príncipe (Cabral and Duarte 2011). However, although many of the children of immigrants entering the Portuguese education system had familiarity with the host nation language the academic success of those students was, nevertheless, very low, (Baganha and Marques 2001). Of the immigrant children who entered the Portuguese educational system, only $12 \%$ completed secondary school and those in attendance consistently achieved lower average ratings in mathematics and Portuguese language national tests, when compared with native students (Seabra 2012). Such studies and others (see Motti-Stefanidi 2015, for an examination of academic success of Greek-Pontian immigrant youth in Greek schools) can imply a relative negative influence of acculturative stressors such as lower societal status and discrimination over the advantages that knowledge of the host language can impart to first and second generation immigrant children.

Given the Portuguese context with respect to migration, there is the significance of the population under study for the research and understanding of acculturative dynamics. Consequently, within the general framework of bidimensional theories of acculturation (Berry 1997; Bourhis et al. 1997) and research (e.g., Ojeda et al. 2014; Schachner et al. 2014b) there is an investigation of the relationships of host and heritage acculturation orientations and perceived cultural distance with academic performance among immigrant students within Portugal. 


\section{Research intentions}

Given the burgeoning immigrant population in immigrant-receiving societies, how well immigrant adolescents fare in schools is critical for the overall economic growth and development of immigrant-receiving societies (SuárezOrozco et al. 2008). Moreover, to the best of our knowledge, no study using Portugal data has documented the relations of first- and second-generation immigrant adolescents' perceived cultural distance, perceived cultural orientations-heritage culture (i.e., culture of immigrant parents, families, and communities; Berry et al. 2006) and host culture (i.e., culture and country in which immigrant adolescents now live; OECD 2013)—with their academic performance in reading, mathematics, and science. Therefore, the present study, using data collected from the Portuguese students who took part in the 2012 Program for International Student Assessment (PISA) survey, aimed at examining the relationships of home language, perceived cultural distance, and perceived acculturation orientations of first- and second-generation immigrant adolescents with their performance in reading, mathematics, and science. Specifically, the following research questions guided our study:

1. To what extent are first- and second-generation immigrant adolescent students' perceived cultural orientations and perceived cultural distance related to their performance on the PISA reading, mathematics, and science assessments?

2. Does language spoken at home predict first- and second-generation immigrant adolescent students' performance on the PISA reading, mathematics, and science assessments?

\section{Method}

\subsection{Data}

Data for the study were drawn from the PISA 2012 database (http://www.oecd. org/pisa/data). PISA assesses the reading, mathematics, and science literacy of 15 -year-olds in participating countries. Over half-a-million 15-year-olds from 65 countries and economies took part in the PISA 2012 surveys and assessments (OECD 2013). A total of 5722 15-year-olds from Portugal participated in the PISA 2012 surveys and assessments. Of these, 399 students were immigrant adolescents (first-generation $=235$ [female $=127$, male $=108], M_{\text {age }}=15.80$ years, $S D=.30$; second-generation $=164$ [female $=83$, male $=81$ ], $M_{\text {age }}=15.76$ years, $S D=.29)$. First-generation immigrant adolescents included students who were born outside of Portugal and whose parents were both born outside of Portugal, whereas second-generation immigrant adolescents comprised students who were born in Portugal, but their parents were born in another country (see OECD 2013). 


\subsection{Measures and variables}

\subsubsection{Academic performance}

The PISA 2012 reading, mathematics, and science performance scales were the outcome measures in the study (see OECD 2014). The focus of PISA 2012 was on mathematics. The PISA 2012 assessments included 110 mathematics items, 53 science items, and 44 reading items. These cognitive items included both simple multiple-choice and complex multiple-choice items. OECD constructed the reading, mathematics, and science achievement scales using item response theory (IRT) scaling techniques (OECD 2014).

\subsubsection{Acculturation orientations}

Immigrant adolescents' perceived acculturation orientations were measured using the two PISA scaled indices (OECD 2014): heritage culture-orientation (4 items; e.g., "I like to have heritage culture friends"; Cronbach's $\alpha=.73$ and .85 for firstand second-generation immigrant adolescents, respectively) and host culture-orientation (4 items; e.g., "I spend a lot of time with host culture friends"; Cronbach's $\alpha=.83$ and .84 for first- and second-generation immigrant adolescents, respectively). All items were rated on a 4-point Likert-type scale, ranging from $1=$ strongly disagree to $4=$ strongly agree. OECD constructed the acculturation orientation measures employing IRT scaling techniques (OECD 2014).

\subsubsection{Perceived cultural distance}

Immigrant adolescents' perceived cultural distance was measured using the PISA scaled index, cultural distance between host and heritage culture (3 items; e.g., "The values of people in the host culture and in the heritage culture are the same"; Cronbach's $\alpha=.74$ and .84 for first- and second-generation immigrant adolescents, respectively). All items were rated on a 4-point Likert-type scale, ranging from $1=$ strongly disagree to $4=$ strongly agree. OECD constructed the cultural distance scale employing IRT scaling techniques (OECD 2014).

\subsubsection{Language spoken at home}

Students were asked to report their home language ( $1=$ language of the test, $0=$ other language).

\subsubsection{Control variables}

The control variables in the present study were gender $(1=$ female, $0=$ male $)$, and the PISA index of economic, social, and cultural status (ESCS; a proxy measure of family SES, comprising three components such as the highest occupational 
status of parents, the highest education level of parents, and home possessions; OECD 2014).

\section{Results}

The descriptive statistics for all variables and measures in the study are reported in Table 1. Hierarchical regression analyses were conducted to answer the research question. Host culture-orientations, heritage culture-orientations, cultural distance between host and heritage culture were the independent variables in the regression equation. The PISA reading, mathematics, and science performance scales were the dependent variables. Control variables, gender and ESCS, were entered on the first step of the regression equation and the independent variables were entered on the second step of the regression equation.

\subsection{First-generation immigrant adolescents}

On the first step, control variables accounted for $24 \%, 17 \%$, and $17 \%$ of the variance in first-generation immigrant adolescents' reading, mathematics, and science performance, respectively (see Table 2). The addition, home language, perceived acculturation orientations, and perceived cultural distance measures, accounted for an additional $9 \%, 14 \%$, and $12 \%$ of the variance in reading, mathematics, and science performance, respectively. An examination of the betas for the variables and measures at the second step indicated that first-generation immigrant adolescents' cultural distance between host and heritage culture had statistically significant negative relationships with their reading $(\beta=-.22, p<.05)$ and mathematics $(\beta=-.18$, $p<.05)$ performance; heritage culture-oriented strategies had statistically significant negative relationships with their reading $(\beta=-.28, p<.05)$, mathematics $(\beta=-.32$, $p<.05)$ and science $(\beta=-.29, p<.05)$ performance; and host culture-oriented

Table 1 Descriptive statistics

\begin{tabular}{|c|c|c|c|c|}
\hline & \multicolumn{2}{|c|}{$\begin{array}{l}\text { First-generation immi- } \\
\text { grant adolescents }\end{array}$} & \multicolumn{2}{|c|}{$\begin{array}{l}\text { Second-generation } \\
\text { immigrant adoles- } \\
\text { cents }\end{array}$} \\
\hline & M & SD & M & SD \\
\hline Gender & .54 & .50 & .51 & .50 \\
\hline Economic, social, and cultural status (ESCS) & -.67 & 1.06 & -.57 & 1.23 \\
\hline Language spoken at home & .54 & .50 & .93 & .25 \\
\hline Cultural distance between host and heritage culture & -.08 & .89 & .19 & 1.06 \\
\hline Heritage culture-oriented strategies & -.18 & .85 & -.13 & 1.07 \\
\hline Host culture-oriented strategies & -.07 & .88 & -.17 & 1.08 \\
\hline Reading achievement & 450.18 & 99.59 & 460.18 & 99.81 \\
\hline Mathematics achievement & 450.42 & 96.36 & 445.42 & 95.22 \\
\hline Science achievement & 453.37 & 87.59 & 448.32 & 86.29 \\
\hline
\end{tabular}




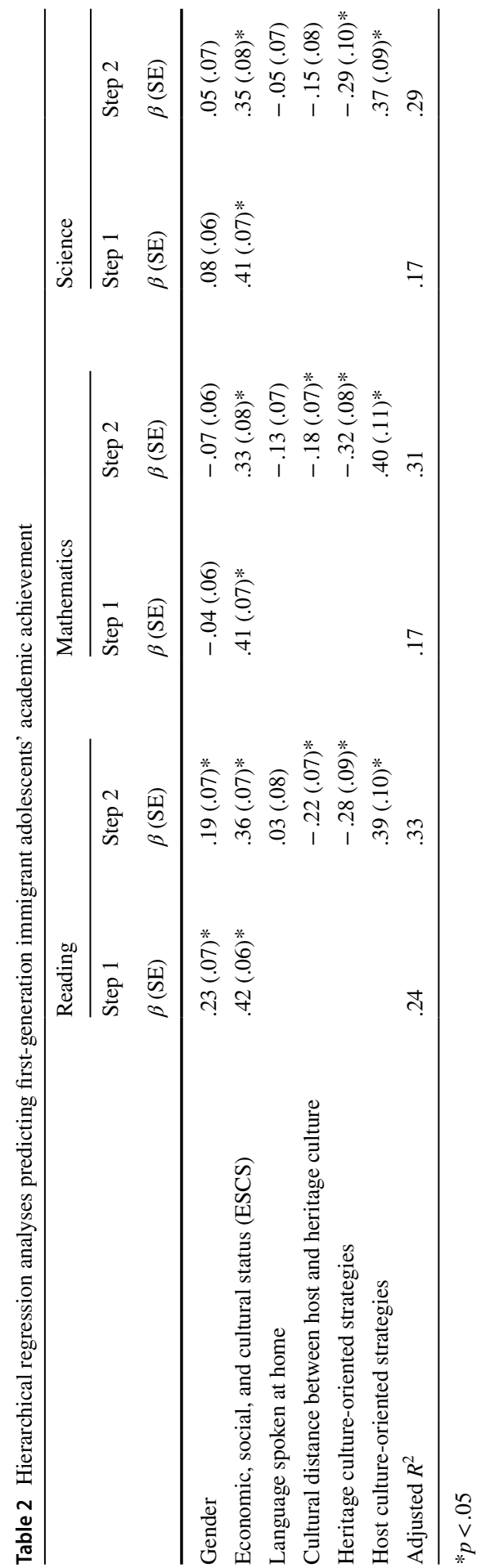


strategies had statistically significant positive relationships with their reading $(\beta=.39, p<.05)$ and mathematics $(\beta=.40, p<.05)$ and science $(\beta=.37, p<.05)$ performance. However, language spoken at home was not statistically significantly associated with first-generation immigrant adolescents' performance on the PISA reading, mathematics, and science assessments (see Table 2).

\subsection{Second-generation immigrant adolescents}

On the first step, control variables accounted for $22 \%, 22 \%$, and $16 \%$ of the variance in second-generation immigrant adolescents' reading, mathematics, and science performance, respectively (see Table 3). The addition, home language, perceived acculturation orientations, and perceived cultural distance, accounted for an additional $13 \%, 18 \%$, and $13 \%$ of the variance in reading, mathematics, and science performance, respectively. An examination of the betas for the variables and measures at the second step indicated that second-generation immigrant adolescents' heritage culture-oriented strategies had statistically significant negative relationships with their reading $(\beta=-.41, p<.05)$, mathematics $(\beta=-.41, p<.05)$, and science $(\beta=-.44, p<.01)$ performance; host culture-oriented strategies had statistically significant positive relationships with their reading $(\beta=.25, p<.05)$ and science $(\beta=.26, p<.05)$ performance. However, host-oriented strategies were not statistically significantly related to second-generation immigrant adolescents' mathematics performance. Furthermore, language spoken at home was not statistically significantly related to second-generation immigrant adolescents' performance on the PISA reading, mathematics, and science assessments (see Table 3).

\section{Discussion}

Drawing from the cultural orientation strategies framework emergent from the bidimensional models of acculturation (e.g., Berry 1997; Bourhis et al. 1997), the current study examined the performance levels of adolescent children of immigrants in Portugal in order to investigate the link between academic achievement and two specific features of the acculturation process. First, the relationship between firstand second-generation immigrant adolescents' host or heritage cultural orientation and its link to academic achievement; and the presence or absence of an association between perceived cultural distance and the academic achievement of first and second generation immigrant adolescents. Second, the presence of a link between host country language proficiency and academic performance.

With respect to the relationship between language proficiency and academic achievement, no significant association was found in either first- or second-generation immigrant adolescents. This finding in accordance with research that details the complex relationship between host language proficiency and academic achievement within immigrant populations (e.g., Baganha and Marques 2001; Seabra 2012) implies that the relative negative influence of acculturative stressors such as lower societal status and discrimination (Motti-Stefanidi 2015) may attenuate the 


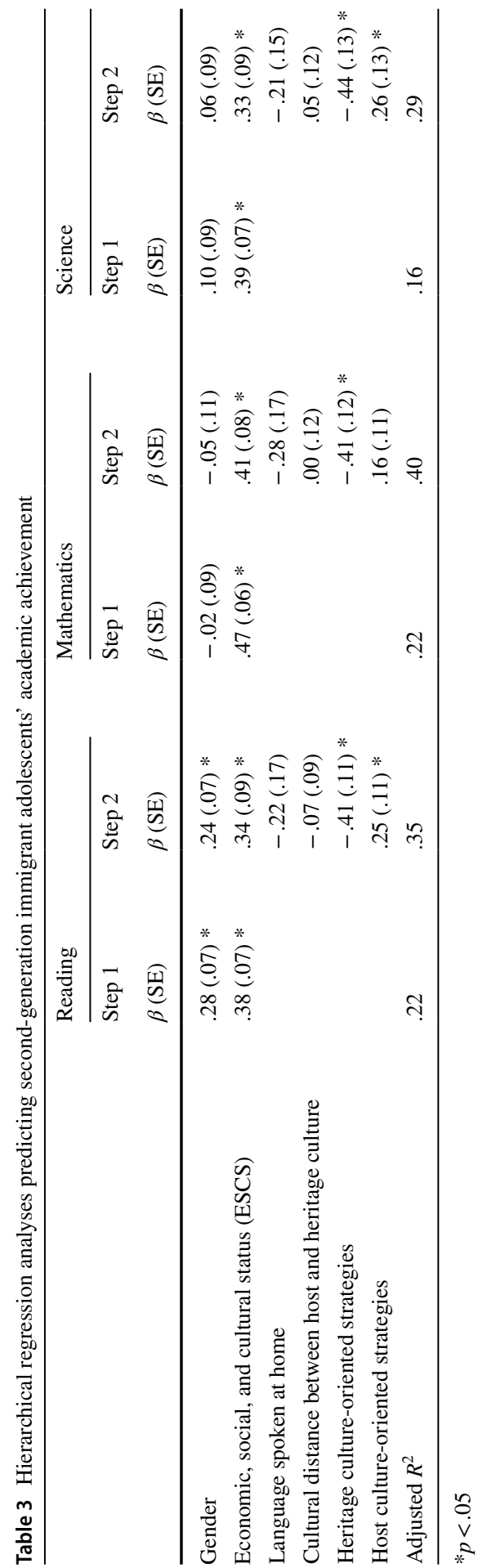


advantages that knowledge of the host language can impart to first and second generation immigrant children: thereby prompting the need for further and more specific investigation of psychological and sociocultural factors (see, Colon and Sanchez 2010; Trickett and Birman 2005) that may influence the host language proficiencyacademic achievement relationship.

\subsection{Acculturation orientation}

The findings of the present study underline the pivotal role of culture-orientations in the academic success of both first- and second-generation immigrant adolescents in an immigrant-receiving society. This study builds on studies that have demonstrated the benefits of utilizing and accommodating to aspects of the host culture by immigrant groups undergoing acculturation (e.g., Benet-Martínez et al. 2002; Colon and Sanchez 2010; Motti-Stefanidi et al. 2012; Trickett and Birman 2005; Ward 2013).

The study found that of immigrant adolescents in Portugal who took the PISA 2012 survey those who reported a host-culture orientation demonstrated a significant advantage in academic achievement. Within first-generation immigrant students the advantage was seen in all areas, reading, mathematics and science and within second-generation immigrant adolescents the advantage was seen in reading and science.

Furthermore, the results also demonstrated the negative association between a focus upon heritage culture orientations by both first- and second-generation immigrant adolescents and academic achievement in mathematics, reading, and science. These findings suggest the academic performance related importance of cultivating an environment that encourages a more adaptive bicultural stance that values context specific utilization and/or adoption of important features of the host culture in addition to the maintenance of the heritage culture (Bourhis et al. 1997; Ward 2013). Moreover, the results endorse the need to evaluate government initiated policies and programs that may inadvertently encourage isolationism and marginalisation within immigrant populations. Policies and programs should be assessed to ensure opportunities to support and encourage immigrant adolescents, who are strongly attached to their cultures of origin but weakly linked to their societies of settlement to develop proficiency in context appropriate employment of both host and heritage cultureoriented strategies.

Additionally, these measures would fall in line with considerations that generally suggest a combination of strong heritage and host culture-oriented strategies to be beneficial for the successful inclusion of immigrant youth in immigrant-receiving societies (Berry et al. 2006; Bochner 1982; Ward 2013). Such government led programs may go a long way in the avoidance of practices by adolescents that are considered counterproductive in terms of successful life chances and that instead lead to improved integration and ultimate success of immigrant adolescents in immigrantreceiving societies (e.g., Ogbu 1992). It is of course recognized that the acceptance of government-initiated policies and programs by the groups within society as a whole requires more than simple legislation. Despite the general acceptance of the advantage offered by adoption of a biculturally competent stance (Berry et al. 
2006; Bochner 1982; LaFromboise et al. 1993), it is necessarily the case that mere possession of host nation cultural characteristics, such as language, religion or even ethnicity, individually or collectively, is not a guarantee of academic success and/or favourable life chances (e.g., Motti-Stefanidi 2015). Success additionally requires at least a level of perceived cultural similarity (Suanet and van de Vijver 2009), cultural immersion (Murdock and Ferring 2015) and, moreover, societal acceptance (Motti-Stefanidi 2015) to take place and as such underlines the complexity of developing an effective and viable bicultural position for academic success.

\subsection{Perceived cultural distance}

In accordance with the expectations of perceived cultural hypothesis (Babiker et al. 1980), upon entry to a new cultural setting, immigrants, through their interaction with the host culture, necessarily make subjective comparisons (be they intended or not) between aspects of the host and heritage environment that will result in an understanding of similarities and differences between their valuation of cultural distance (Babiker et al. 1980; Searle and Ward 1990). This perceived cultural distance may moderate cross-cultural adjustment (Stahl and Caligiuri 2005) that can in turn induce a level of acculturative challenge and stress (Bochner 1982; Furnham and Bochner 1982; Geeraert and Demoulin 2013). The resultant stress may then impact upon the ability of the immigrant to operate successfully within the new environment.

The study found no significant relationship between perceived cultural distance and academic achievement for second-generation immigrant adolescents but does indicate a significant negative relationship between perceived cultural distance and academic achievement within first-generation immigrant adolescents in reading and mathematics. This negative relationship between perceived cultural distance and performance can be considered in terms of the lower bicultural competence (e.g., Benet-Martínez and Haritatos 2005; Berry 2005; Bourhis et al. 2010) of the firstgeneration immigrant adolescents, whose comparative lack of competency can result in them being less adept at manoeuvring within the host culture and hence more susceptible to the acculturative stresses (Bochner 1982; Furnham and Bochner 1982; Geeraert and Demoulin 2013) that accompany the ongoing cross-cultural adjustment in the face of cultural differences (Stahl and Caligiuri 2005). Conversely, the second-generation immigrant adolescents being born and raised within the host nation will necessarily have a developed knowledge and understanding of the similarities and differences between their heritage culture and the host culture and this greater relative familiarity of and experience within the host culture would allow them to operate with better bicultural competence and efficacy (LaFromboise et al. 1993). This enabled them to utilize their knowledge of both heritage and host cultural expectations to alter and adapt behaviour to fit the social context without the accompanying stress and the subsequent impact upon their academic performance. Support for this interpretation comes from studies conducted by Portes and his colleagues (Portes and Rumbaut 2001; Portes et al. 2009) who demonstrated how the adoption of selective acculturation, i.e., the measured utilization of both heritage 
and host cultural strategies, by second-generation immigrants can lead to improved educational achievement.

These findings, therefore, further support the recommendations made previously regarding the value of governmental programmes that promote and support the utilization of effective bicultural strategies in first-generation immigrant adolescents.

\subsection{Limitations}

The current study highlighted a number of issues. One relates to the utilization of a fixed dataset that necessarily imposes a limitation in the size and available details of the sample population examined. Consequently, the dataset prohibited fuller investigation of the first- and second-generation immigrant students' on a country by country basis that may have yielded a more culturally contextualized analysis of the factors involved in the choice of a heritage or host culture-oriented strategy and their relationship to academic achievement. Additionally, due to limitations in the size of the immigrant populations that make up the PISA 2012 dataset, the current study cannot satisfactorily ascertain whether the results were significantly influenced by the demographic complexion of the immigrant groups. Yet another limitation of the study is the use of self-report measures. Although self-report measures are widely used in social and behavioral science research, they have been criticized for social desirability bias and acquiescence bias (see Nederhof 1985).

\subsection{Conclusions}

Research suggests that the acculturative process undertaken by migrants is not only stressful (Berry 1997, 2006; Searle and Ward 1990; Ward 2001) but also multifaceted (Makarova and Birman 2015; Schwartz et al. 2010). Nevertheless, facets can be examined to investigate the level of advantage they afford immigrant populations and their children.

The present study demonstrated an adopted focus upon heritage culture orientations by both first- and second-generation immigrant students is linked to lower achievement in mathematics, reading, and science. Conversely, there are clear links between utilization of host cultural orientations and improved academic achievement in reading, mathematics and science literacy for first-generation immigrant adolescents that is continued into the second-generation for reading and science. These findings demonstrate the need for supportive measures and mechanisms that promote the adoption of a viable bicultural stance that values utilization of important features of the host culture in addition to the maintenance of the heritage culture. Additionally, also demonstrated is the benefit of further investigation of the factors that may influence the promotion and acceptance of a bicultural position by immigrants within host communities. Likewise, the demonstration of the changing nature of the relationship between perceived cultural distance and academic achievement further stresses the need for programs that foster selective acculturation and, therefore, improved opportunities for academic success. 
Open Access This article is licensed under a Creative Commons Attribution 4.0 International License, which permits use, sharing, adaptation, distribution and reproduction in any medium or format, as long as you give appropriate credit to the original author(s) and the source, provide a link to the Creative Commons licence, and indicate if changes were made. The images or other third party material in this article are included in the article's Creative Commons licence, unless indicated otherwise in a credit line to the material. If material is not included in the article's Creative Commons licence and your intended use is not permitted by statutory regulation or exceeds the permitted use, you will need to obtain permission directly from the copyright holder. To view a copy of this licence, visit http://creativecommons.org/licen ses/by/4.0/.

\section{References}

Areepattamannil, S., \& Kaur, B. (2012). Factors predicting science achievement of immigrant and nonimmigrant students: A multilevel analysis. International Journal of Science and Mathematics Education, 5, 1183-1207.

Arends-Tóth, J., \& Van de Vijver, F. J. R. (2003). Multiculturalism and acculturation: Views of Dutch and Turkish-Dutch. European Journal of Social Psychology, 33, 249-266.

Arends-Tóth, J., \& Van de Vijver, F. J. (2006). Issues in the conceptualization and assessment of acculturation. In M. H. Bornstein \& L. R. Cote (Eds.), Acculturation and parent-child relationships: Measurement and development (pp. 33-62). Mahwah, NJ: Lawrence Erlbaum Associates Publishers.

Babiker, I. E., Cox, J. L., \& Miller, P. (1980). The measurement of cultural distance and its relationship to medical consultations, symptomatology, and examination performance of overseas students at Edinburgh University. Social Psychiatry, 15, 109-116.

Baganha, M. I., \& Marques, J. C. (2001). Imigracao e politica: O caso Portugues (Immigration and Politics: The Portuguese case) (1st ed.). Lisbon, Portugal: Fundação Luso-Americana para o Desenvolvimento.

Bankston, C. L., III, \& Zhou, M. (1997). The social adjustment of Vietnamese American adolescents: Evidence for a segmented-assimilation approach. Social Science Quarterly, 78, 508-523.

Benet-Martínez, V., \& Haritatos, J. (2005). Bicultural identity integration (BII): Components and psychosocial antecedents. Journal of Personality, 73, 1015-1050.

Benet-Martínez, V., Leu, J., Lee, F., \& Morris, M. W. (2002). Negotiating biculturalism: Cultural frame switching in biculturals with oppositional versus compatible cultural identities. Journal of CrossCultural Psychology, 33(5), 492-516.

Berry, J. W. (1990). Acculturation and adaptation: A general framework.

Berry, J. W. (1992). Acculturation and adaptation in a new society. International Migration, 30, 69-86.

Berry, J. W. (1997). Immigration, acculturation, and adaptation. Applied Psychology: An International Review, 46, 5-43.

Berry, J. W. (2003). Conceptual approaches to acculturation. American Psychological Association.

Berry, J. W. (2005). Acculturation: Living successfully in two cultures. International Journal of Intercultural Relations, 29(6), 697-712.

Berry, J. W. (2006). Stress perspectives on acculturation. In D. L. Sam \& J. W. Berry (Eds.), The Cambridge handbook of acculturation psychology (pp. 43-57). New York: Cambridge University Press.

Berry, J. W. (2017). Theories and models of acculturation. In S. J. Schwartz \& J. B. Unger (Eds.), The Oxford handbook of acculturation (pp. 15-28). New York: Oxford University Press.

Berry, J. W., Phinney, J. S., Sam, D. L., \& Vedder, P. (Eds.). (2006). Immigrant youth in cultural transition: Acculturation, identity, and adaptation across national contexts. Mahwah: Erlbaum.

Blomquist, G. (2006). Measuring quality of life. In R. Arnott \& D. McMillen (Eds.), A companion to urban economics (pp. 480-501). Oxford: Wiley-Backwell.

Bochner, S. (Ed.). (1982). Cultures in contact: Studies in cross-cultural interaction. Oxford: Pergamon.

Boski, P. (2008). Five meanings of integration in acculturation research. International Journal of Intercultural Relations, 32(2), 142-153.

Bourhis, R. Y., Moise, L. C., Perreault, S., \& Senecal, S. (1997). Towards an interactive acculturation model: A social psychological approach. International Journal of Psychology, 32, 369-386.

Bourhis, R. Y., Montaruli, E., El-Geledi, S., Harvey, S. P., \& Barrette, G. (2010). Acculturation in multiple host community settings. Journal of Social Issues, 66, 780-802. 
Cabral, S., \& Duarte, C. (2011). Immigrants in the Portuguese labour market. Banco de Portugal Economic Bulletin, 1, 97-116.

Cheng, C. Y., \& Leung, A. K. Y. (2013). Revisiting the multicultural experience-Creativity link: The effects of perceived cultural distance and comparison mind-set. Social Psychological and Personality Science, 4, 475-482.

Clément, R. (1986). Second language proficiency and acculturation: An investigation of the effects of language status and individual characteristics. Journal of Language and Social Psychology, 5, 271-290.

Colon, Y., \& Sanchez, B. (2010). Explaining the gender disparity in Latino youth's education: acculturation and economic value of education. Urban Education, 45, 252-273.

Dimitrova, R., Bender, M., \& van de Vijver, F. J. R. (Eds.). (2014). Global perspectives on well-being in immigrant families. New York: Springer.

Duong, M. T., Badaly, D., Liu, F. F., Schwartz, D., \& McCarty, C. A. (2016). Generational differences in academic achievement among immigrant youths: A meta-analytic review. Review of Educational Research, 86, 3-41.

Dustmann, C., Frattini, T., \& Lanzara, G. (2011). Educational achievement of second-generation immigrants: an international comparison. CreAM Discussion Paper No 16/11.

Esser, H. (2006). Migration, language and integration. WZB. Retrieved from https://wzb.eu/www2000/ alt/aki/files/aki_research_review_4.pdf.

Feliciano, C., \& Lanuza, Y. R. (2017). An immigrant paradox? Contextual attainment and intergenerational educational mobility. American Sociological Review, 82, 211-241.

Fuligni, A. J. (1997). The academic achievement of adolescents from immigrant families: The roles of family background, attitudes, and behaviour. Child Development, 68, 351-363.

Fuligni, A. J., Witkow, M., \& Garcia, C. (2005). Ethnic identity and the academic adjustment of adolescents from Mexican, Chinese, and European backgrounds. Developmental Psychology, 41(5), 799.

Furnham, A., \& Bochner, S. (1982). Social difficulty in a foreign culture: An empirical analysis. In S. Bochner (Ed.), Cultures in contact: Studies in cross-cultural interaction (pp. 161-198). Oxford: Pergamon.

Galchenko, I., \& van de Vijver, F. J. (2007a). The role of perceived cultural distance in the acculturation of exchange students in Russia. International Journal of Intercultural Relations, 31, 181-197.

Galchenko, I., \& Van De Vijver, F. J. (2007b). The role of perceived cultural distance in the acculturation of exchange students in Russia. International Journal of Intercultural Relations, 31(2), 181-197.

Geeraert, N., \& Demoulin, S. (2013). Acculturative stress or resilience? A longitudinal multilevel analysis of sojourners' stress and self-esteem. Journal of Cross-Cultural Psychology, 44, 1241-1262.

Gibson, M. A. (1988). Accommodation without assimilation: Sikh immigrants in an American high school. Ithaca: Cornell University Press.

Gordon, M. M. (1964). Assimilation in American life. New York: Oxford. University Press.

Greenman, E. (2013). Educational attitudes, school peer context, and the "immigrant paradox" in education. Social Science Research, 42, 698-714.

Güngör, D. (2007). The interplay between values, acculturation and adaptation: A study on Turkish-Belgian adolescents. International Journal of Psychology, 42(6), 380-392.

Han, W. J. (2012). Bilingualism and academic achievement. Child Development, 83(1), 300-321.

Hofstede, G. (1980). Culture's consequences: international differences in work-related values. Beverly Hills: Sage.

Hofstede, G. (2001). Culture's consequences: Comparing values, behaviours, institutions, and organizations across nations (2nd ed.). Thousand Oaks: Sage.

International Organization for Migration. (2013). World migration report 2013: Migrant well-being and development. Geneva: Author.

Jia, F., Gottardo, A., Koh, P. W., Chen, X., \& Pasquarella, A. (2014). The role of acculturation in reading a second language: Its relation to English literacy skills in immigrant Chinese adolescents. Reading Research Quarterly, 49, 251-261.

Kao, G., \& Tienda, M. (1995). Optimism and achievement: The educational performance of immigrant youth. Social Science Quarterly, 76, 331-343.

Kerr, Z. (2007). Parental influences on mathematics achievement of children of immigrant backgrounds (Doctoral dissertation, University of British Columbia).

Kibria, N. (2000). Race, ethnic options, and ethnic binds: Identity negotiations of second-generation Chinese and Korean Americans. Sociological Perspectives, 43(1), 77-95. 
Kim, Y. M., Newhill, C., \& López, F. (2013). Latino acculturation and perceived educational achievement: Evidence for a bidimensional model of acculturation among Mexican-American children. Journal of Human Behaviour in the Social Environment, 23, 37-52.

Kim, H. Y., \& Suárez-Orozco, C. (2015). The language of learning: The academic engagement of newcomer immigrant youth. Journal of Research on Adolescence, 25, 229-245.

LaFromboise, T., Coleman, H. L., \& Gerton, J. (1993). Psychological impact of biculturalism: Evidence and theory. Psychological Bulletin, 114, 395-410.

López, E. J., Ehly, S., \& García-Vásquez, E. (2002). Acculturation, social support and academic achievement of Mexican and Mexican American high school students: An exploratory study. Psychology in the Schools, 39, 245-257.

Makarova, E., \& Birman, D. (2015). Cultural transition and academic achievement of students from ethnic minority backgrounds: A content analysis of empirical research on acculturation. Educational Research, 57, 305-330.

Massey, D. (1990). Social structure, household strategies, and the cumulative causation of migration. Population Index, 56(1), 3-26. https://doi.org/10.2307/3644186.

Massey, D. S., Arango, J., Hugo, G., Kouaouci, A., Pellegrino, A., \& Taylor, J. E. (1994). An evaluation of international migration theory: The North American case. Population and Development Review, 20, 699-751.

Mok, A., Morris, M. W., Benet-Martinez, V., \& Karakitapoğlu-Aygün, Z. (2007). Embracing American culture: Structures of social identity and social networks among first-generation biculturals. Journal of Cross-Cultural Psychology, 38, 629-635.

Motti-Stefanidi, F. (2015). Risks and resilience in immigrant youth adaptation: Who succeeds in the Greek school context and why? European Journal of Developmental Psychology, 12, 261-274.

Motti-Stefanidi, F., Berry, J., Chryssochoou, X., Sam, D. L., \& Phinney, J. (2012). Positive immigrant youth adaptation in context: Developmental, acculturation, and social psychological perspectives. In A. S. Masten, K. Liebkind, \& D. J. Hernandez (Eds.), Realizing the potential of immigrant youth (pp. 117-158). Cambridge: Cambridge University Press.

Mumford, D. B. (1998). The measurement of culture shock. Social Psychiatry and Psychiatric Epidemiology, 33, 149-154.

Murdock, E., \& Ferring, D. (2015). Bilingualism=biculturalism? Reflections on the relationship between language and culture. Retrieved from http://orbilu.uni.lu/handle/10993/21756.

Nederhof, A. J. (1985). Methods of coping with social desirability bias: A review. European Journal of Social Psychology, 15, 263-280.

Nguyen, A.-M. D., \& Benet-Martínez, V. (2013). Biculturalism is linked to adjustment: A meta-analysis. Journal of Cross-Cultural Psychology, 44, 122-159.

Niemeyer, A. E., Wong, M. M., \& Westerhaus, K. J. (2009). Parental involvement, familismo, and academic performance in Hispanic and Caucasian Adolescents. North American Journal of Psychology, 11, 613-631.

Ogbu, J. U. (1992). Adaptation to minority status and impact on school success. Theory into Practice, 31, 287-295.

Ojeda, L., Castillo, L. G., Rosales Meza, R., \& Piña-Watson, B. (2014). Mexican Americans in higher education: Cultural adaptation and marginalization as predictors of college persistence intentions and life satisfaction. Journal of Hispanic Higher Education, 13, 3-14.

Organization for Economic Cooperation and Development. (2013). PISA 2012 results: What students know and can do. Paris: Author.

Organization for Economic Cooperation and Development. (2014). PISA 2012 technical report. Paris: Author.

Phinney, J. S., Horenczyk, G., Liebkind, K., \& Vedder, P. (2001). Ethnic identity, immigration, and wellbeing: An interactional perspective. Journal of Social Issues, 57, 493-510.

Plunkett, S. W., \& Bámaca-Gómez, M. Y. (2003). The relationship between parenting, acculturation, and adolescent academics in Mexican-origin immigrant families in Los Angeles. Hispanic Journal of Behavioural Sciences, 25, 222-239.

Portes, A., Fernández-Kelly, P., \& Haller, W. (2009). The adaptation of the immigrant second generation in America: A theoretical overview and recent evidence. Journal of Ethnic and Migration Studies, 35, 1077-1104.

Portes, A., \& Rumbaut, R. G. (2001). Legacies: The story of the immigrant second generation. Berkeley: University of California Press. 
Rienties, B., \& Tempelaar, D. (2013). The role of cultural dimensions of international and Dutch students on academic and social integration and academic performance in the Netherlands. International Journal of Intercultural Relations, 37, 188-201.

Rosenbaum, E., \& Rochford, J. A. (2008). Generational patterns in academic performance: The variable effects of attitudes and social capital. Social Science Research, 37, 350-372.

Ryder, A. G., Alden, L. E., \& Paulhus, D. L. (2000). Is acculturation unidimensional or bidimensional? A head-to-head comparison in the prediction of personality, self-identity, and adjustment. Journal of Personality and Social Psychology, 79, 49-65.

Santiago, C. D., Gudiño, O. G., Baweja, S., \& Nadeem, E. (2014). academic achievement among immigrant and U.S.-born Latino adolescents: associations with cultural, family, and acculturation factors. Journal of Community Psychology, 42, 735-747.

Schachner, M. K., Van de Vijver, F. J., \& Noack, P. (2014a). Family-related antecedents of early adolescent immigrants' psychological and sociocultural school adjustment in Germany. Journal of CrossCultural Psychology, 45, 1606-1625.

Schachner, M. K., Van de Vijver, F. J. R., \& Noack, P. (2014b). Characteristics of the country of origin and immigrant children's psychological and sociocultural school adjustment. In L. T. B. Jackson, D. Meiring, F. J. R. Van de Vijver, E. S. Idemudia, \& W. K. Gabrenya Jr. (Eds.), Toward sustainable development through nurturing (or appreciating) diversity (pp. 47-64). Melbourne: International Association of Cross-Cultural Psychology.

Schwartz, S. H. (1992). Universals in the content and structure of values: Theory and empirical tests in 20 countries. In M. Zanna (Ed.), Advances in experimental social psychology (Vol. 25, pp. 1-65). New York: Academic Press.

Schwartz, S. J., Unger, J. B., Zamboanga, B. L., \& Szapocznik, J. (2010). Rethinking the concept of acculturation: Implications for theory and research. American Psychologist, 65, 237-251.

Seabra, T. (2012). Desigualdades de desempenho escolar: etnicidade, género e condição social em escolas básicas da Área Metropolitana de Lisboa (School performance inequalities: ethnicity, gender and social condition in basic schools in Lisbon's urban areas). Sociologia, Revista Da Faculdade de Letras Da Universidade Do Porto, (Special issue: Imigração, Diversidade e Convivência Cultural [Immigration, Diversity and Cultural Coexistence]), 185-210.

Searle, W., \& Ward, C. (1990). The prediction of psychological and sociocultural adjustment during cross-cultural transitions. International Journal of Intercultural Relations, 14, 449-464.

Shin, H. (2004). Parental involvement and its influence on children's school performance: A comparative study between Asian (Chinese and Koreans) Americans and Mexican-Americans (Unpublished doctoral dissertation), Columbia University, New York, NY.

Snauwaert, B., Soenens, B., Vanbeselaere, N., \& Boen, F. (2003). When integration does not necessarily imply integration: Different conceptualizations of acculturation orientations lead to different classifications. Journal of Cross-Cultural Psychology, 34(2), 231-239.

Stahl, G. K., \& Caligiuri, P. (2005). The effectiveness of expatriate coping strategies: The moderating role of culture distance, position level, and time on the international assignment. Journal of Applied Psychology, 90, 603-615.

Suanet, I., \& Van de Vijver, F. J. (2009). Perceived cultural distance and acculturation among exchange students in Russia. Journal of Community \& Applied Social Psychology, 19, 182-197.

Suárez-Orozco, C., Gaytan, F. X., Bang, H. J., Pakes, J., O’Connor, E., \& Rhodes, J. (2010). Academic trajectories of newcomer immigrant youth. Developmental Psychology, 46, 602-618.

Suárez-Orozco, C., Suárez-Orozco, M. M., \& Todorova, I. (2008). Learning a new land: Immigrant students in American society. Cambridge: Harvard University Press.

Trickett, E. J., \& Birman, D. (2005). Acculturation, school context, and school outcomes: Adaptation of refugee adolescents from the former Soviet Union. Psychology in the Schools, 42, 27-38.

Trinh, N. H., Rho, Y. C., Lu, F. G., \& Sanders, K. M. (Eds.). (2009). Handbook of mental health and acculturation in Asian American families. New York: Springer.

Van De Vijver, F. J., \& Phalet, K. (2004). Assessment in multicultural groups: The role of acculturation. Applied Psychology, 53, 215-236.

Vollebergh, W. A., Iedema, J., \& Raaijmakers, Q. A. (2001). Intergenerational transmission and the formation of cultural orientations in adolescence and young adulthood. Journal of Marriage and Family, 63(4), 1185-1198.

Ward, C. (2001). The ABCs of acculturation. In D. Matsumoto (Ed.), The handbook of culture and psychology (pp. 411-445). New York: Oxford University Press. 
Ward, C. (2007). Ethno-cultural identity conflict in Korean youth in New Zealand. In Seventh Biennial Conference of the Asian Association of Social Psychology, Kota Kinabalu, Malaysia.

Ward, C. (2013). Probing identity, integration and adaptation: Big questions, little answers. International Journal of Intercultural Relations, 37(4), 391-404.

Ward, C., \& Kennedy, A. (1993). Psychological and Socio-cultural adjustment during cross-cultural transitions: A comparison of secondary students overseas and at home. International Journal of Psychology, 28, 129-147.

Ward, C., \& Searle, W. (1991). The impact of value discrepancies and cultural identity on psychological and sociocultural adjustment of sojourners. International Journal of Intercultural Relations, 15(2), 209-224.

Ward, C., Stuart, J., \& Kus, L. (2011). The construction and validation of a measure of ethno-cultural identity conflict. Journal of Personality Assessment, 93, 462-473.

Wood, P. B., \& Clay, W. C. (1996). Perceived structural barriers and academic performance among American Indian high school students. Youth \& Society, 28(1), 40-61.

Yeh, C. J. (2003). Age, acculturation, cultural adjustment, and mental health symptoms of Chinese, Korean, and Japanese immigrant Adolescents. Cultural Diversity and Ethnic Minority Psychology, 9, 34-48.

Yeh, C. J., \& Inose, M. (2002). Difficulties and coping strategies of Chinese, Japanese, and Korean immigrant students. Adolescence, 37, 69-82.

Publisher's Note Springer Nature remains neutral with regard to jurisdictional claims in published maps and institutional affiliations.

Dr. Michael Melkonian is an assistant professor at the Emirates College for Advanced Education, Abu Dhabi, United Arab Emirates within the Division of Counselling, Special Education and Educational Neuroscience. His research assumes an integrative approach that interweaves cross-cultural and educational psychology.

Dr. Shaljan Areepattamannil is an associate professor in the Division of Assessment and School Evaluation at the Emirates College for Advanced Education, Abu Dhabi, United Arab Emirates. He conducts interdisciplinary research at the intersection of social psychology and STEAM education.

Dr. Luisa Menano is an artist and independent researcher working from London. Her interests are interdisciplinary and embody the connection between art and education. Her recent research has included assessing the challenge of integrating art and technology in education

Dr. Patricia Fidalgo is an assistant professor at the Emirates College for Advanced Education, Abu Dhabi, United Arab Emirates in the Curriculum and Instruction Division. Her recent research has investigated the use of technological devices by undergraduate students and the usefulness of learning information literacy skills in the enhancement of 21th century skills. 